\title{
Passwords
}

Volume 13 | Issue 1

Article 14

$12-20-2012$

\section{Y Comenzamos}

Jordan Wilson-Dalzell

jowilson@students.pitzer.edu

Follow this and additional works at: http://scholarship.claremont.edu/passwords

Part of the Art and Design Commons, Creative Writing Commons, and the Photography $\underline{\text { Commons }}$

\section{Recommended Citation}

Wilson-Dalzell, Jordan (2012) "Y Comenzamos," Passwords: Vol. 13: Iss. 1, Article 14. DOI: 10.5642/passwrd.20121301.14 Available at: http://scholarship.claremont.edu/passwords/vol13/iss1/14

This Story is brought to you for free and open access by the Journals at Claremont at Scholarship @ Claremont. It has been accepted for inclusion in

Passwords by an authorized administrator of Scholarship@ Claremont. For more information, please contact scholarship@cuc.claremont.edu. 


\section{Two Pieces by}

Jordan Wilson-Dalzell

\section{Y Comenzamos}

(a creation story)

Our four legs stand here tonight, though yours have yet to unfurl. Heads bowed, we pay homage to the future we will create, you and I. One day, this world will belong to you. Fearing the day you escape my womb, ground shakes beneath me. I hush it, ignoring the jealousy of an older sibling. Nothing will ever rival your glory, though my other offspring will tell you differently. From the gaunt limbs of my rooted sons to the mouths of my airborne daughters, there will be anger upon your arrival. None of your brothers and sisters, neither the stoic mountains nor the warm-bloods of the desert will love you.

"Be careful baby, be careful."

Tiny toes kick the walls of my earthen belly. My miracle is feisty! You have swollen me from the deserts of Mexico to the glaciers of Russia.

My lips croon, "Together we are giant."

"Mamí -- Mamí?"

I stumble. Sound has met you?!

"Yes baby?"

"I am ready."

"Then, I will make you now, my child. Knuckles will knead you human, forming hands with piano keys, and ears from a boom box's noisy breaths. We will build you a shape from decibels so you will know how to listen."

"To what?" he wonders.

"To the wind as she sings to the water of her journeys." I stride forward as you walk a path within me: the first of the miles you will conquer to distinguish yourself.

"Your internal organs will be woven from the clean and quiet of afterstorm air, and the pungent passion of sulfur spewing from my pores. Smell is the deepest sense- with it as your core, you will know the true nature of each creature."

"And what is my true nature?"

"Questioning all that can be seen. Discovering this planet's secrets. You are a product of the senses- intended to lead quietly." 
He grows still as I spread myself wide to birth him; my hips crack ridges into the dirt to mark where he will be born.

"No! Bring me unto this world in loud sweeping strokes; I will not be new and silent."

"Hush, little one. You have not earned your words, yet I name you Adán, first born of your kind, youngest of my brood."

Adán, leaps full grown from my uterus-stubble lining his chin, potential reflecting in his eyes. My son wanders in the wilderness for a decade-living with his siblings in peace and harmony. He dives for clams with the otters, and climbs his rooted brothers with squirrels.

But one day he weaves a net from the ground's green hair so the dolphin can catch more fish. And makes a cutting tool from metal for Beaver to cut down trees faster. It becomes all about superlatives: quickest, most, best. I begin to worry Adán does not understand. Even so, when he asks for it- I make him a mate from his left rib and they fill the world with parts of themselves.

But he is not satiated. Adán wants to make conquerors out of his kind-the youngest of my creations. They must all be his. Everything- every mountain peak, each piece of my heart, - must bow to him. He discovers fire, and the world is over. Forests are incinerated by callous hands, creaking and moaning as they are eaten alive. My fleet-footed deer gallop into the arms of his red-eyed hunters. The beasts within them open their jaws- ignorance dripping from their tongues like hunger's juices- for the kill, but not to feed. Smoke curdles the air, choking his sisters from the sky.

They litter me with the corpses my womb once carried. But they are not finished, Adán's humans sharpen their fingers into knives and try to dig my heart from the earth. When they cannot, Adán comes.

I look at him, covered in his siblings' blood. "My child, your contraptions have scoured the plains of my body. You have traversed all of my skin. What are you doing?"

"Looking for you. I'm just trying to earn my words." He laughs, coldly. "You cannot say they aren't mine now. You are not my home anymore." "Look around you, you have no home," I say fervently.

"That is ENOUGH!" He shouts, reaching for me.

"I am done with you. It is my time now. Mamí-Eres anciana. Dejalo." Smiling, I go to him. "But my child, I do not stop existing when I die. I just rise again.” 